\title{
Problems of Constitutional and Legal Regulation of Artificial Intelligence
}

\author{
Zyryanov I.A.
}

\begin{abstract}
Saratov State Law Academy, Saratov, Russia
\end{abstract}
Email: zyryanovv@yandex.ru

\begin{abstract}
The paper discusses various models of the legal regulation of artificial intelligence (AI) in Russia and foreign countries. Currently, there are no scientific concepts of constitutional and legal regulation of AI, the development of which is especially in demand in the field of ensuring social rights and freedoms of human and citizen. It is being proved that the development of a model of constitutional and legal regulation, when AI is not a quasi-subject of law but an object thereof, is the most reasonable. The special position of AI as an object of legal relations requires the adoption of a special federal constitutional law on AI in Russia, which will establish mandatory state licensing of AI, restrictions on its activity, and responsibility for the results of its activity, which is also required to protect social human rights from illegal actions of AI.
\end{abstract}

Keywords: artificial intelligence, legal regulation, Constitution of the Russian Federation, social human

rights

\section{INTRODUCTION}

The creation of AI in the world is more focused on commercial goals and the digital economy and its use in the implementation of social rights and freedoms of man and citizen is not sufficiently motivated. For this reason, the most serious risk is the possibility of teaching any kind of AI algorithms for social discrimination of people on various grounds, which is prohibited by Article 19 of the Constitution of the Russian Federation. Thus, in the USA, there are already cases of discrimination of people with black skin by AI when determining second offense in American courts [1], on the grounds of gender, age, and religion when hiring for work [2]. In the UK, China, Japan, and the Republic of Korea, the AI-predicted trial system is partially used. This makes judges dependent on the AI-predicted outcome of the case based on statistical data. For Russia, this is not an option due to the lack of case law and the analogy of criminal law [3].

The reason for this is that nowadays, the ethical aspects of AI machine programming remain at the level of selfregulation and co-regulation of producer communities, for example, in the UK [4] and Germany [5] and the European Statute of Ethics adopted in 2018 [6] is of recommendatory nature. The United Nations recognizes that the risks of replacing human labor with robots are also increasing [7].

However, today, the effectiveness of using AI for communicating robots with older people, providing them with social support has been proven in Japan, Australia, the USA, and the Netherlands [8]. The Da Vinci surgical robot performs complex operations [9]; in robot surgery, the number of patent applications at WIPO is constantly growing [3]; in Finland, robots can teach children and migrants 23 languages [10]. In Russia, the 2018 Presidential national projects "Healthcare," "Science," and "Education" also provide for the development and use of new AI technologies in the social sphere.

The practical concern of the relationship of human rights with AI, as well as the blurring of the boundaries between humans and machines, was expressed in the PACE Recommendation dated 04/28/2017 [11]. In view of the aforesaid, the rights of a robotic man (a hybrid model of AI and humans) and the establishment of guarantees for their implementation, especially social ones, are of particular significance.

In this regard, the purpose of this study is to actualize the topic of developing a scientific concept of constitutional and legal regulation of $\mathrm{AI}$ for the subsequent use of $\mathrm{AI}$ in the implementation of social rights and freedoms of human and citizen.

\section{METHODS}

During the study, we collected information on supranational and national models of legal regulation of AI from 40 sources.

The following research methods were used:

formal-legal, during the analysis of subjects and objects of constitutional relations, measures of legal responsibility; comparative method, used when comparing the legal regulation of AI in Russia and foreign countries; and structural analysis, allowed developing organizational measures to introduce the concept of "artificial intelligence" into the constitutional legislation. 


\section{RESULTS}

According to the researchers, currently, foreign countries have no legislative consolidation concept of artificial intelligence, such as the recognition of AI or its software by subjects of law [12]. Although the number of regulatory acts in the world on robotics in civil law regulation is rapidly increasing. However, the lack of proper constitutional and legal regulation of relations in the field of AI, neurosystems, and cyberphysical systems carries certain social risks for states, including the use of AI for criminal purposes.

For example, the Law on the Development and Distribution of Smart Robots [13] is effectively working in the Republic of Korea. According to doctrine and jurisprudence in the USA and Canada, the author of the invention may only be a person, not an animal, not an AI; including a person in cases when the objects of the law were created by the computer without the participation of a human (Articles 9, 178 of the UK Act 1998 on Copyright, Industrial Designs, and Patents) [12]. In Germany, the car manufacturer is responsible at the legislative level for the damage to unmanned vehicles with AI [14], although in the USA, there is a draft law recognizing AI of an unmanned vehicle as a driver [15].

The indicated problem is already being raised by Russia within the framework of international treaties regarding the delimitation of criminal liability and bringing to responsibility for damage to an unmanned vehicle and persons inside it and exercising direct control over the safety of its operation [14].

Gradually, isolated cases arise when AI is recognized as the subject of legal relations in fact but not by law. Thus, the humanoid robot Sophia received the citizenship of Saudi Arabia; in 2014, AI was included in the board of directors of a venture company in the UK [16]; the exchange robot (program) in the Central Bank of the Russian Federation can make transactions in the interests of human [13]. Since 2017, the European Parliament of the $\mathrm{EU}$, as high as at the supranational legal level, has been proposing in the future to determine complex autonomous robots as electronic persons possessing the legal personality [17].

The prevailing practice and the appearance of the first court cases, more and more promote the idea of giving the features of the subject of law to artificial intelligence with the assignment of a number of functions and duties performed by man. For example, in May 2020, it is planned to consider a high-profile case in a lawsuit filed by a Chinese businessman against a manufacturer of an exchange robot that lost $\$ 25$ million in the market in 1 day [18].

In this regard, more and more concepts of the legal status of AI and robots are being developed in domestic and foreign science and practice. It is proposed to give AI the status of a quasi-subject of legal relations [15], a subject of civil law $[19,20]$, a subject of the civil procedure [20], an electronic person [17, 21], and a legal entity [22]. More exotic models of legal regulation are reviewed by the analogy with a robot: with a child, an animal with limited legal capacity, and a slave in Roman private law [13].

The extrapolation of foreign scientific concepts on the recognition of AI as a subject of criminal and administrative law (with the exception of discussions on the complete reprogramming, removal of errors or disposal), with differentiation of responsibility for the actions of a "strong" AI and human-controlled AI [23] is also unproductive. Indeed, the recognition of AI as a subject carries the danger of shifting responsibility from the authorities to AI for economic crises, irreversible loss of life from the actions of AI surgeons and military vehicles.

Foreign authors in isolated cases consider the possibility of AI acting as a subject of constitutional law [24]. This problem has not been developed in domestic science. For example, in one of the monographs of 2019, the authors devote 4 pages to the constitutional aspects of robotics [25].

One of the few studies is a comprehensive monograph by P.M. Morkhata 2017, containing separate chapters on AI and human rights, the involvement of AI units in public administration. The author proposes to consider AI units as subjects of law without recognition of their full legal capacity or to recognize the independent responsibility of an AI unit for unfair medical practice [23].

Developers of draft federal laws on robotics [19] or amendments to the Civil Code of the Russian Federation [20] also consider robot agents as independent subjects of civil circulation and responsibility.

The above models are united by the fact that their authors are practically unanimous in the idea of the need to secure special legal status for AI units since AI can be a source of increased danger, as well as violate the rights and freedoms of others. They distinguish between types of responsibility and cast doubt on the lack of evidence of AI being aware of its guilt, its ability to bear responsibility for their actions, and the lack of specific sanctions that AI could "feel."

We agree with the positions of scientists based on Lawrence Solum: "Artificial intelligence (objects with artificial intelligence) and even objects with full-fledged artificial intelligence (cyber-subjects) are not people and can not be positioned as similar or identical to people. This is the most direct argument of all, it can be argued that only people may have constitutional rights" $[24,26]$.

In foreign constitutions, various groups of individuals, organizations, public law entities, authorities, and their officials are usually recognized as subjects of law. AI is not among them; it is difficult to equate it to any subject so that in the future, it also acts as a sectoral subject. Therefore, the recognition of an AI or smart robot as a subject of law should initially occur at the constitutional legal level.

Thus, AI in the structure of legal relations is not a subject and acts as a unique virtual object. From the standpoint of the Constitution of the Russian Federation, AI can be regarded as information technology, a means of ensuring human rights and freedoms, constitutional economy; property protected by the law of private, state, municipal, 
and other forms of ownership (Part 2 of Article 8) or by the intellectual property regime (Part 1 of Article 44). AI in the system of objects of legal relations refers to the group of tangible (socio-economic) or intangible values.

\section{DISCUSSION}

The rapid development of the digital economy and AI in Russia originates at the sub-legislative level of political acts of the President of the Russian Federation and the Government of the Russian Federation of 2017-2019 [27, 28, 29]. Special constitutional and legal regulation of AI has not been established, except for state judicial authorized systems. AI regulation will reach a new level if, in a popular vote in 2020, amendments to the Constitution of the Russian Federation are approved, guaranteeing in Article 71 the protection of the safety of the individual and society when using information technologies and circulating digital data [30].

The reviewed problems and risks of AI do not cover all matter of a constitutional nature that remains outside the existing Constitution of the Russian Federation and require a higher level of legal regulation than ordinary federal laws. Therefore, within the framework of the Constitution of the Russian Federation, it is now not the Civil Code of the Russian Federation but the adoption of a special Federal Constitutional Law "On Artificial Intelligence" (FCL) that is able to solve the issue of giving the legal capacity to AI.

Despite the fact that the Constitution of the Russian Federation does not directly indicate the adoption of such a law, the Federal Assembly of the Russian Federation may adopt federal constitutional laws on other issues under the jurisdiction of Russia in accordance with Article 71 of the Constitution of the Russian Federation, if it considers that they consolidate the relations characterizing the actual constitution of society. Thus, federal constitutional laws on the Supreme Court of the Russian Federation, on courts of general jurisdiction, which were not provided for by the Constitution of the Russian Federation, had already been adopted earlier.

Some scientists put the regulation of AI to the level of constitutive rules in the Civil Code of the Russian Federation [31], others put it to the "bottom-to-top" level or mainly to the substatutory level [13]. Other regulatory models are proposed, based solely on the mechanism of legal regulation or allowing the level of technical regulation (at the base of state regulation) or the state delegation of its functions to professional communities at the level of self-regulation and co-regulation [32].

At the same time, it is the development of a special federal constitutional law that can resolve the issue of giving an AI partial or limited legal capacity or giving it special legal status as an object of constitutional and sectoral relations. The latter option seems more acceptable to us within the framework of the theory of constitutional law. The most reasonably will be the construction of a model of legal regulation aimed at simplifying the application of laws when AI is not a quasi-subject of law but an object of the law. At the same time, technical regulation should be the base of legal regulation of the use of digital technologies, where ethical regulation will be an important limitation of them, including self-regulation [32].

Further development to fill the gaps requires unification in the FCL. It should give the concept of the definition of AI, its main features, requirements for AI developers regarding the moral and ethical principles of machine programming. Cases of contesting the results of the activity of each AI in the courts should be registered, for which the requirements for the description in a clear language of the algorithms of how the results of the activity of the AI are obtained should be established.

By the analogy of law, AI restrictions may be imposed even now in Part 4 of Article 13 and Part 3 of Article 55 of the Constitution of the Russian Federation. At the same time, the FCL requires the introduction of additional prohibitions on the introduction of mandatory collection and registration of AI biometric personal data to obtain basic identification documents, without which it is impossible to exercise civil rights, get an education, social security, and pensions.

$\mathrm{AI}$ is the most developed at the state level In India, since 2009, the state system of compulsory biometric registration of an individual "Aadhaar" was introduced, without which it is practically impossible to exercise civil rights, receive state services, social security, and nutrition. This served as the base for numerous appeals to the Supreme Court of India in view of the leakage and insecurity of the personal data of millions of citizens, the death of poor people and children who did not obtain food. The court issued a ruling dated 09/26/2018 stating "No one shall be denied benefits due to the lack of an Aadhaar card" [33].

In more than 80 countries, such registration is still partially connected with obtaining electronic passports and the exercise, at first glance, of the political rights of citizens. Actually, without scanning and identification systems, it is difficult to exercise the social rights and freedoms of a person, without reference to citizenship, especially when such requirements are already put to obtain a residence permit in a number of countries.

The opposite situation has developed In Ukraine. In 2018, The Supreme Court in claims of believers declared it illegal to replace paper passports with biometric ones "Introduction of the up-to-date technologies should not be uncontested and compulsory" [34].

The planned introduction of compulsory electronic and genetic passports in Russia, when, according to the VCIOM 2018 data, 2/3 of citizens oppose this [35], or a proposal of digital identification (ID) for all the inhabitants of the planet within the UN framework, when $40 \%$ of respondents in the world do not trust technology [36], may lead to an antisocial result, as in India. Therefore, the introduction of $\mathrm{AI}$ in various areas of society should be based on the achievements of constitutional sociology, nationwide discussions, referenda taking into account religious traditions and characteristics in each legal system. 
The FCL is advisable to consolidate specific types of various state and commercial automated systems, cyberphysical systems, neurosystems, and robots subject to mandatory state licensing. It is also reasonable to preliminarily scientifically develop and establish in the FCL a list of AIs that should be withdrawn and limited in civil circulation, exclusive areas, and industries, in which AIs may operate independently.

It will be necessary to establish a special state interdepartmental body that defines the list of such AIs, exclusive areas of operation, and judicial arbitration, which in the future itself may consist of neurostems. So far, this function is performed by the Intellectual Property Rights Court, which issued the first Russian Decree dated July 24, 2018, in the field of Big Data [37] (the case has not yet been closed). The owners of the VKontakte social network demanded that the defendants should be prohibited from using open user data to provide services for assessing the creditworthiness of borrowers to third parties using a computer program of intellectual analysis. The emergence of such disputes in the future, including ones of a constitutional nature, is inevitable, to which, by the way, the court did not pay attention (according to the division of people by social and property grounds by AI).

The establishment of licensing AI, as well as the introduction of restrictions and prohibitions on its operation, in the FCL will not be enough here. As President Vladimir Putin correctly noted, "Artificial intelligence is not only the future of Russia, it is the future of all mankind. Here we see tremendous opportunities and threats that are difficult to predict today" [38].

Therefore, it will be required to develop a new, constitutional type of state liability insurance since the Russian Federation should assess the political risks of introducing $\mathrm{AI}$ into the constitutional and digital economy and other areas by the analogy with political risk insurance. The difference of the proposed model will be in the insurance of domestic political risks with the state as an insurer. Constitutional risks are the danger of massive infliction of harm to society by AI and a significant infringement by AI of constitutional interests, rights, and freedoms of the individual.

As for legal responsibility, its establishment and delineation are required only for developers, programmers, owners and holders, crackers of AI units with the introduction of special sanctions, which they may also incur through objects, AI units, since the latter as subjects of law are not fully capable of awareness of the consequences of their malicious actions, as well as they are not capable to and correct themselves. At the same time, owners and holders should bear both independent types of sectoral responsibility in the presence of fault and responsibility through AI units, where sanctions will fulfill preventive functions regarding the unlawful use of an object (AI) or its independent or human-controlled operation.

The reviewed Russian bills $[19,20]$ seem infeasible to us since they do not offer relevant solutions to the problems of delineation of responsibility between AI and its creators, as well as the establishment of specific sanctions for them. They do not comply with the principle of legal certainty.

In the view of legal futurism, the authors could be invited to adopt a digital death (killing) of the AI, temporary blocking of the AI, imprisonment in "quarantine" or "ban," defining it as a virus, a malicious program with a low level of intelligence, recognition of the lack of intelligence in the computer program, disconnecting from the Internet and virtual environment, disconnecting from power. Among the sanctions, one may also propose a ban on the production of a specific AI or withdrawal from circulation, a ban on the production of clones, digital copies of AI, new intellectual property products, disposal, a ban on AI "entering" the country or leaving it in the case of access to state or commercial secret, etc.

Although the sanctions we have proposed above have not been developed in science as measures of constitutional legal responsibility, they do occur in actual relations. it is possible to propose to "apply" them to the objects of legal relations, which actually will be borne by the owners and holders of AI units. We derive these theses by analogy, which is also consistent with the theory of restricting the activity of objects of law. For example, the information legislation prescribes the possibility of temporarily blocking sites and Internet platforms with illegal content by the prosecutor's office and Roskomnadzor; actually, website creators or website owners are subject to sectoral sanctions.

When a "strong" AI is created, it will be possible to propose introducing the most convenient model of legal regulation of $\mathrm{AI}$ as an object of law with quasi-rights and quasi-obligations. This can be done with AI by the analogy with the Constitution of Ecuador of 2008, the first in the world to recognize the legally enforceable rights of nature to restoration, existence, and reproduction (Articles 7174). The legal capacity of nature is recognized by the Constitution of Mexico City of 2017 (Article 13), by decisions of municipalities in 10 US states, two laws of Bolivia aimed at protecting Mother Earth. It was repeatedly defended by the courts of these countries. A similar paradigm for recognizing the rights of Nature is forming by the UN [39].

The main limitation of the activity of AI in such a model is that it should be able to interact safely with the real world and people, so all fundamental quasi-rights of AI should come from this obligation. For example, the right to freedom of movement in space, the right to energy, the right to access information, the right to the Internet, the right to education (self-education), the right to freedom of creativity and the creation of new results of intellectual activity and virtual reality, the creation of digital copies of $\mathrm{AI}$ or new AI, and the duty of anonymization.

In this model, it will be required to create state neurosystems that will control all other AIs, a state intellectual supervisor, an "educator," which is programmed to suspend operation and deactivate cyberphysical systems and computer programs that behave inappropriately. 
[5] I. Nigmatullin, Germaniya pridumala tri eticheskikh pravila dlya bespilotnykh avto.URL:https://hightech.fm/2016/09/12/3-

rules/(12.01.2019)

[6] Yevropeyskaya eticheskaya khartiya ob ispol'zovanii iskusstvennogo intellekta $\mathrm{v}$ sudebnykh sistemakh i okruzhayushchikh ikh realiyakh (Strasburg, 3-4 dekabrya 2018 goda).URL: https://rm.coe.int/ruethical-charter-en-version-17-12-2018-mdl-060920192-/16809860f4

[7] Dostoynyy trud, navyki i vozmozhnosti dlya molodezhi, OON v Rossii.2019. №3. S.9.

[8] Jordan Abdi, Ahmed Al-Hindawi, Tiffany Ng, Marcela P. Vizcaychipi. Scoping review on the use of socially assistive robot technology in elderly care//BMJ Open.2018; 12; 8(2): e018815. DOI: 10.1136/bmjopen2017-018815

[9] Elektronnyy resurs. URL: http://www.davincisurgery.com/da-vincisurgery/davinci-surgical-system/

[10] V.A. Zhilkin, Iskusstvennyy intellekt i tsifrovyye tekhnologii $\mathrm{v}$ yuridicheskoy deyatel'nosti $\mathrm{v}$ tsifrovoy real'nosti (na primere Finlyandii)//Zhurnal zarubezhnogo zakonodatel'stva i sravnitel'nogo pravovedeniya. 2018. № 5, s.16-21.

[11] Recommendation № 2102 (2017) of Parliamentary Assembly of the Council of Europe «Technological convergence, artificial intelligence and human rights», $28 \quad$ April 2017. URL:https://assembly.coe.int/nw/xml/XRef/XrefXML2HTML-en.asp?fileid=23726\&lang=en

[12] P. Rolinson, Ye.A. Ariyevich, D.Ye. Yermolina, Ob"yekty intellektual'noy sobstvennosti, sozdavayemyye s pomoshch'yu iskusstvennogo intellekta: osobennosti pravovogo rezhima v Rossii i za rubezhom, Zakon.2018. № 5, s.63-71.

[13] Yuridicheskaya kontseptsiya robotizatsii: monografiya, Antonova N.V., Bal'khayeva S.B., Gaunova ZH.A. i dr.; otv. red. Tikhomirov YU.A., Nanba S.B. M.: Prospekt, 2019. Dostup iz SPS «Konsul'tantPlyus».

[14] A.I. Korobeyev, A.I. Chuchayev, Bespilotnyye transportnyye sredstva: novyye vyzovy obshchestvennoy bezopasnosti,Lex russica.2019. №2, s.9-28. DOI: 10.17803/1729-5920.2019.147.2.009-028 al Academy of Engineering, 2011. URL https://www.raeng.org.uk/publications/other/engineerin g-ethics-in-practice-full 
[26] I.V. Ponkin, A.I. Redkina, Artificial Intelligence from the point of view of law, Vestnik RUDN. Series: Jurisprudence. 2018.V. 22. No. 1, p. 96. DOI: 10.22363 / 2313-2337-2018-22-1-91-109

[27] Ukaz Prezidenta RF ot 07.05.2018 g. № 204 «O natsional'nykh tselyakh i strategicheskikh zadachakh razvitiya Rossiyskoy Federatsii na period do 2024 goda» (red. ot 19.07.2018), SZ RF. 2018. № 20.St. 2817. «Normy grazhdanskogo prava o robototekhnike» URL:http://robopravo.ru/riezoliutsiia_ies

[18] A. Royzman, Birzhevoy robot sygral protiv svoyego «khozyaina».URL: https://www.kommersant.ru/doc/3967462/(12.01.2020)

[19] V.V. Arkhipov, V.B. Naumov, Iskusstvennyy intellekt $\mathrm{i}$ avtonomnyye ustroystva $\mathrm{v}$ kontekste prava: o razrabotke pervogo $\mathrm{v}$ Rossii zakona o robototekhnike, Trudy SPIIRAN.2017. V.6, s.51,54,57. DOI: $10.15622 / \mathrm{sp} .55 .2$

[20] Dentons razrabotala pervyy v Rossii zakonoproyekt o robototekhnike. URL:https://www.dentons.com/ru/insights/alerts/2017/j anuary/27/dentons-develops-firstrobotics-draft-law-inrussia (27.01.2019)

[21] O.A. Yastrebov, Diskussiya o predposylkakh dlya prisvoyeniya robotam pravovogo statusa «elektronnykh lits», Voprosy pravovedeniya.2017. № 1.

[22] G.A. Gadzhiyev, Ye.A. Voynikanis, Mozhet li robot byt' sub"yektom prava? (poisk pravovykh form dlya regulirovaniya tsifrovoy ekonomiki, Pravo.2018. № 4 , s. 45 .

[23] P.M. Morkhat, Iskusstvennyy intellekt: pravovoy vzglyad. M.: Buki Vedi, 2017, s. 70, 132,136,137,149,150,167,168-202, 203-219.

[24] L.B. Solum, Legal Personhood for Artificial Intelligences. North Carolina Law Review.70(4), (1992) pp.1258-1259.

[25] Roboty zayavlyayut o svoikh pravakh: doktrinal'no-pravovyye osnovy i nravstvennoeticheskiye standarty primeneniya avtonomnykh robotizirovannykh tekhnologiy i apparatov: kollektivnaya monografiya / pod red. A.YU. Mamycheva, A.YU. Mordovtseva, G.V. Petruk. M.: RIOR, 2019， s.50,51,62,63,65,155,156,224. DOI: https://doi.org/10.29039/02027-2
[28] Rasporyazheniye Pravitel'stva RF ot 28.07.2017. № 1632-r «Ob utverzhdenii programmy «Tsifrovaya ekonomika Rossiyskoy Federatsii», SZ RF.2017. №32. St.5138 (utratilo silu).

[29] Ukaz Prezidenta RF ot 10.10 .2019 g. № $490 \ll \mathrm{O}$ razvitii iskusstvennogo intellekta $\mathrm{v}$ Rossiyskoy Federatsii», SZ RF.2019. № 41.St. 5700.

[30] Zakon RF o popravke $\mathrm{k}$ Konstitutsii RF ot 14.03 .2020 g. №1-FKZ «O sovershenstvovanii regulirovaniya otdel'nykh voprosov organizatsii publichnoy vlasti», Rossiyskaya gazeta.2020.16 marta

[31] Konstitutsiya ne budet zashchishchat' iskusstvennyy intellekt - sud'ya KS Gadzhiyev.URL: http://rapsinews.ru/judicial_analyst/20181212/2924142 83.html

[32] A.A. Minbaleyev, Modeli regulirovaniya tsifrovykh otnosheniy, Problemy i vyzovy tsifrovogo obshchestva: tendentsii razvitiya pravovogo regulirovaniya tsifrovykh transformatsiy: sb. nauch. tr. po mater. I Mezhdunar. nauch.-prakt. konf. (17-18 oktyabrya 2019 g., Saratov). Saratov, 2019, s.15,16.

[33] Elektronnyy resurs. URL: https://www.thehindu.com/news/resources/article25048 939.ece/binary/AadhaarVerdict.pdf

[34] Resheniye Bol'shoy palaty Verkhovnogo suda Ukrainy 19.09.2018. № 806/3265/17. URL:https://verdictum.ligazakon.net/document/768227 87

[35] A ya protiv! Rossiyskaya gazeta.2018.10 yanv.

[36] Obozreniye «Nauka za rubezhom». 2020. №86, s.8,59.

[37] Postanovleniye Suda po intellektual'nym pravam RF ot 24.07.2018 g. № S01-201/2018 po delu № A40$18827 / 2017$, SPS «Konsul'tant plus».

[38] Elektronnyy resurs. URL: https://www.kommersant.ru/doc/3401255(12.01.2020) 
[39] Doklad General'nogo sekretarya OON ot 19.07.2017 g. «V garmonii s prirodoy». P.27-39. URL:https://undocs.org/ru/A/72/175

[40] N.N.Kovaleva, N.A. Zhirnova, M.V. Filimonova, The Virtual Property under the Legislation of the Russian Federation: Present State and Development Trends/ Proceedings of the 1st International Scientific Conference «Modern Management Trends and the Digital Economy: from Regional Development to Global Economic Growth» (MTDE 2019), pp. 803, 806. 